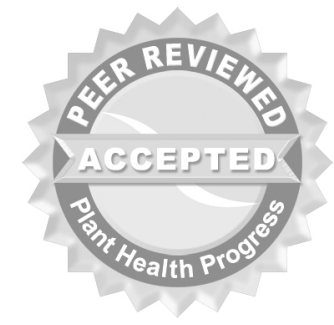

(c) 2010 Plant Management Network.

Accepted for publication 17 May 2010. Published 7 July 2010.

\title{
First Report of Charcoal Rot of Sunflower in Minnesota, USA
}

T. Gulya, USDA-ARS Sunflower Research Unit, Fargo, ND 58102;

A. Mengistu, USDA-ARS Crop Genetics Research Unit, Jackson, TN 38301; and K. Kinzer, N. Balbyshev, and S. Markell, Department of Plant Pathology, North Dakota State University, Fargo, ND 58102

Corresponding author: S. Markell. samuel.markell@ndsu.edu

Gulya, T., Mengistu, A., Kinzer, K., Balbyshev, N., and Markell, S. 2010. First report of charcoal rot of sunflower in Minnesota, USA. Online. Plant Health Progress doi: 10.1094/PHP-2010-0707-02-BR.

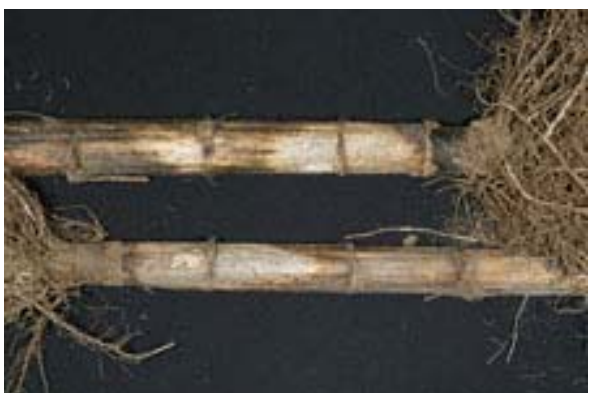
(2009) showing grey girdling lesions at the base of the plant, characteristic of charcoal rot.
Fig. 1. Sunflower stalks from Aldrich, MN

A field of oilseed sunflower (Helianthus annuus L. hybrid Pioneer 63M82') was observed with uneven maturation in west central Minnesota near Aldrich (Todd Co.) in late September 2009. The field's soil type was sandy loam and cropping history was oats in 2008 preceded by four years of alfalfa. Most plants were green, but $37 \%$ of the plants had a brown stem and wilted with senescent leaves. Onethird of these prematurely dead plants ( $12 \%$ ) had 2 to $14 \mathrm{~cm}$ long (avg. 8.5 ) silvery grey girdling lesions at the soil line (Fig. 1). When cut open, every plant with such lesions had small black microsclerotia (Fig. 2A), but lacked horizontal pith compression typically associated with charcoal rot (Fig. 3). Additionally, some stalks exhibited pink pith discoloration, later determined to be due to multiple Fusarium species (3). After plating pith on acidified PDA and incubation at $35^{\circ} \mathrm{C}$, colonies and microsclerotia (but no pycnidia) typical of Macrophomina phaseolina (Tassi) Goid. formed within 7 days. Microsclerotia recovered from plants and those in culture (Fig. 2B) both generally measured between 75 and 175 microns. To access prevalence of charcoal rot in the region, 500 sunflower plants in five strips, each strip approximately $25 \mathrm{~m}$ in length, were visually inspected in 20 fields in a $20 \mathrm{~km}$ radius from the primary affected field. Additionally, soil from 13 of those fields and from the primary affected field were collected by sampling 10 locations spaced at 25-m intervals in a Wpattern. Soil samples were bulked by field and assayed for Macrophomina on potato dextrose agar amended with rifampicin (100 mg/ liter) and tergitol (0.1 $\mathrm{ml}$ ) at the USDA-ARS Plant Pathology Lab in J ackson, TN (4). No charcoal rot symptoms were observed on sunflower plants in any visually inspected fields. However, nine of 13 soil samples (69\%) were positive for Macrophomina, with microsclerotial numbers ranging from 1 to 4 per $1 \mathrm{~g}$ soil, which is low in comparison with counts from fields with other hosts in warmer areas of the Midwest (4). Grower estimated yield in the affected field was $2200 \mathrm{~kg} / \mathrm{ha}$, above the Minnesota state average of $1700 \mathrm{~kg} / \mathrm{ha}$, but it is unclear if charcoal rot impacted yield. This area of Minnesota received in J uly, August, and September $2009,106,75$ and $15 \mathrm{~mm}$ of rain, with average monthly temperatures of 18, 18, and $17^{\circ} \mathrm{C}$, respectively. These conditions were unlikely to stress sunflower or provide conditions optimal for charcoal rot development. Charcoal rot on sunflower is typically seen in hot, arid climates such as Texas (6). It was first observed on sunflower in North and South Dakota in 1998 (2), and was widespread on soybeans recently in Iowa (5), suggesting that Macrophomina may becoming more common in cooler growing areas of Midwestern United 
States. However, in surveys conducted by the National Sunflower Association (1), charcoal rot has been recorded only 35 times in 1854 fields surveyed between 2001 and 2009 in eight states and was not detected during 2007 to 2009. This infrequency of observation could be due in part to the persistent cool and wet climate in recent years, which is unfavorable for charcoal rot disease development. However, with the multitude of Macrophomina hosts in the northern Great Plains and the high incidence of microsclerotia we detected in soil, high disease potential may exist, suggesting that in drier, hotter years the sunflower crop may be affected by this disease.

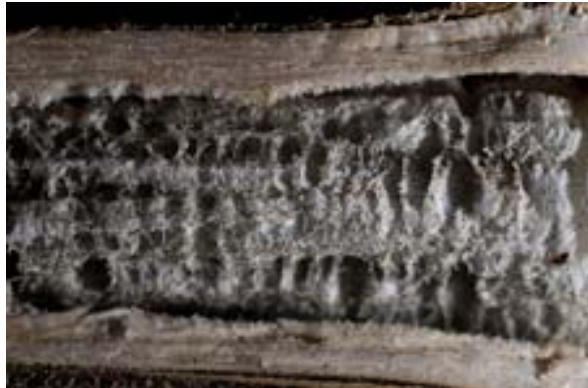

Fig. 2A. Closeup of pith of charcoal rot affected sunflower stalk showing numerous microsclerotia of Macrophomina phaseolina.

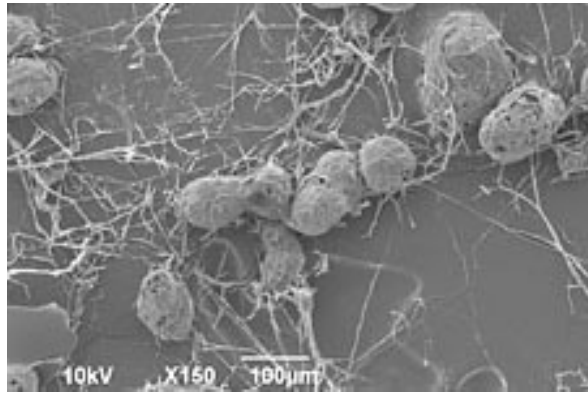

Fig. 2B. Scanning electron micrograph of Macrophomina phaseolina microsclerotia illustrating variable shape and size ranging between 75 and 175 microns.

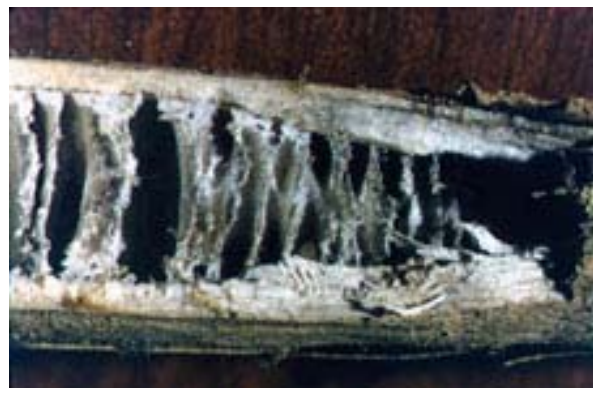

Fig. 3. Longitudinal section of charcoal rot affected sunflower stem showing characteristic compression of the pith tissue into horizontal layers.

Literature Cited

1. Gulya, T. J . 2003. Sunflower crop survey, 2002: Disease assessment across eight states. Online. Res. workshop, Natl. Sunflower Assoc., Mandan, ND.

2. Gulya, T., Krupinsky, J., Draper, M., and Charlet, L. 2002. First report of charcoal rot (Macrophomina phaseolina) on sunflower in North and South Dakota. Plant Dis. 86:923-923.

3. Mathew, F., Kirkeide B., Gulya, T., and Markell, S. First report of pathogenicity of Fusarium sporotrichioides and Fusarium acuminatum on sunflowers in the United States. Online. Plant Health Progress. In press.

4. Mengistu, A., Reddy, K. N., Zablotowicz, R. M., and Wrather, A. J . 2009. Propagule densities of Macrophomina phaseolina in soybean tissue and soil as affected by tillage, cover crop, and herbicide. Online. Plant Health Progress doi:10.1094/PHP-2009-0130-01-RS.

5. Yang, X., and Navi, S. 2005. First report of charcoal rot epidemics caused by Macrophomina phaseolina in soybean in Iowa. Plant Dis. 89:526-526.

6. Yang, S., and Owen, D. 1982. Symptomatology and detection of Macrophomina phaseolina in sunflower in Texas. Phytopathology 72:819-821. 